\title{
ADVENTURES WITH WHITE-WINGED SCOTERS
}

C. STUART HOUSTON, 863 University Drive, Saskatoon, SK S7N 0J8

The White-winged Scoter (Melanitta fusca) is a heavy duck, slow to move, with a laboured flight; when the female flushes from her nest, she is the easiest duck to catch by hand. While banding colonial birds on islands in Redberry Lake, a small amount of effort in banding scoters has, through chance, yielded remarkable results. Included are the five oldest White-winged Scoters in the North American banding system.

My first White-winged Scoter nest on 3 July 1946 was a surprise because of its unusual location, almost exactly half mile from the nearest water, York Lake, south of Yorkton, Saskatchewan; it contained 10 eggs. ${ }^{1}$ My next nest encounter was during a gull-banding expedition to an island at the north end of Last Mountain Lake, 28 June 1955, accompanied by Margaret Belcher and her father, S.R. Belcher. Here on a one-acre island we flushed eight females from their nests amid nettles. The first two had such a slow, laborious takeoff that we realized we should try to pounce upon any others before they got free of the nettles. The next five females, flushed from nests with $14,13,12$, 12, and 12 eggs, were caught and banded, as was a sixth female from a larger island nearby. ${ }^{2}$ The following year, 1956, returning to the same island, we caught four new scoters and recaptured two of the six we had banded the year before. My first gull-banding visits to islands in Redberry Lake capitalized on our new technique; we captured four adult female scoters on their nests 11 July 1956 and another 12, with recapture of one female from the year before, on 30 June 1958.

My move to Saskatoon in 1960 allowed us to keep re-capturing scoters during colonial bird banding visits to Redberry Lake, 1960-1983. This led to an appreciation of the delayed life cycle of this heavy scoter, which only rarely begins breeding before three years of age,$^{3}$ although at Redberry Lake through 1985 the youngest breeding was at five years of age at recapture (technically 4.9 years of age). Fortunately this longevity "appears to offset the low productivity" 3 of never more than 0.5 ducklings produced per pair at Redberry Lake, due to gull predation on newly hatched young. ${ }^{4}$

Agile helpers were a benefit. Joe Schmidt, when 16 or 17 , flushed a female scoter from her nest that gained altitude more quickly than some. I called out: "Tough luck!" but Joe leaped higher than I had thought possible and caught that scoter with his outstretched left hand. As his foot landed beside another scoter nest, that bird flushed; Joe plucked the second bird from the air with his right 
hand. Two scoters caught within one or two seconds! I banded both. Never was a scoter clutch crushed underfoot and never was a scoter injured by being caught.

In helping an American grad student, I did myself and science a favour. Pat Brown, more than halfway through his first summer of a Master's program focused on the biology of White-winged Scoters, telephoned me from Alberta on 14 July 1975 . He had little to show for his first months of study at Miquelon and Jessie lakes in Alberta. A wildlife biologist he met on a lakeshore there had advised him to contact me. Pat asked whether I could teach him how to catch adult scoters on their nests. Gladly. I suggested we meet him and his summer assistant, Chuck Harris, at the shore of Redberry Lake at 4.30 a.m. on 16 July.

Do you mean 4:00 in the afternoon? Pat asked. No, I should be at work at the hospital at 8:00 a.m. and we launch the canoe at a beach more than an hour's drive from Saskatoon. My conscripted helpers on this urgent response were my son Don and his friend Ray Bisha, both going into grade 11 . Within an hour that morning we caught seven adult female scoters; four were new and three others already carried one of my bands from earlier years.

Pat and his wife, Mary Ann, studied scoters intensively at Redberry Lake for six summers. Iowa State University at Ames presented his M.Sc. in 1977 and his landmark dissertation earned him his Ph.D. from the University of Missouri - Columbia in 1981. This pre-eminence earned Pat first authorship of the Whitewinged Scoter for the Birds of North America series in 1997. His co-author was his supervisor for both degrees, renowned waterfowl biologist Leigh $\mathrm{H}$. Frederickson. During six summers, Pat had captures of Houston-banded scoters on 61 occasions.

Good fortune continued. Pat Kehoe, a student of Tom Nudds at the University of Guelph, chose Redberry Lake for his two-summer Master's study in 1984 and 1985. Kehoe recaptured another 19 Houstonbanded scoters while I only re-caught only 13 myself, in the summers when Brown and Kehoe were absent. At Redberry Lake, 50 of the 83 post1959 Houston-banded female scoters were re-caught on 93 occasions. One was 16 years after initial banding and hence was least 18 years old, the continent age record to the present; statistical probability suggests it was more likely at least 21 years old. The second oldest recapture was at 13 years, when at least 15 years, but probably 18 years of age; this scoter had been re-caught at $3,5,8,10,12$ and 13 years after its initial capture on its nest.

Bird banders sometimes jokingly remark that "every bird needs a band." Thanks to the unanticipated arrival of Pat Brown and Pat Kehoe, we have an accurate insight into White-winged Scoter longevity from relatively easy but seemingly random recaptures. 


\section{Acknowledgments}

I thank Pat Brown, Pat Kehoe and the 56 different people who accompanied me on 26 occasions. Since we left the city at 3 or $4 \mathrm{am}$, to canoe across to each island in turn and leave the lake before the sun got hot enough to harm featherless young cormorants and pelicans, only Arnold Nijssen came four times; nine others helped twice. The other 46 chose not to repeat the experience.

1. HOUSTON CS, ANAKA W (2003) Birds of Yorkton - Duck Mountain. SNHS Special Publ. 24.
2. HOUSTON CS (1955) Whitewinged Scoter banding. Blue Jay 13(4):28.

3. KREMENTZ DG, BROWN PW, KEHOE FP, HOUSTON CS (1977) Population dynamics of Whitewinged Scoters. Journal of Wildlife Management 61:222-227.

4. BROWN PW, BROWN MA (1971) Nesting biology of the Whitewinged Scoter. Journal of Wildlife Management 45:38-45.

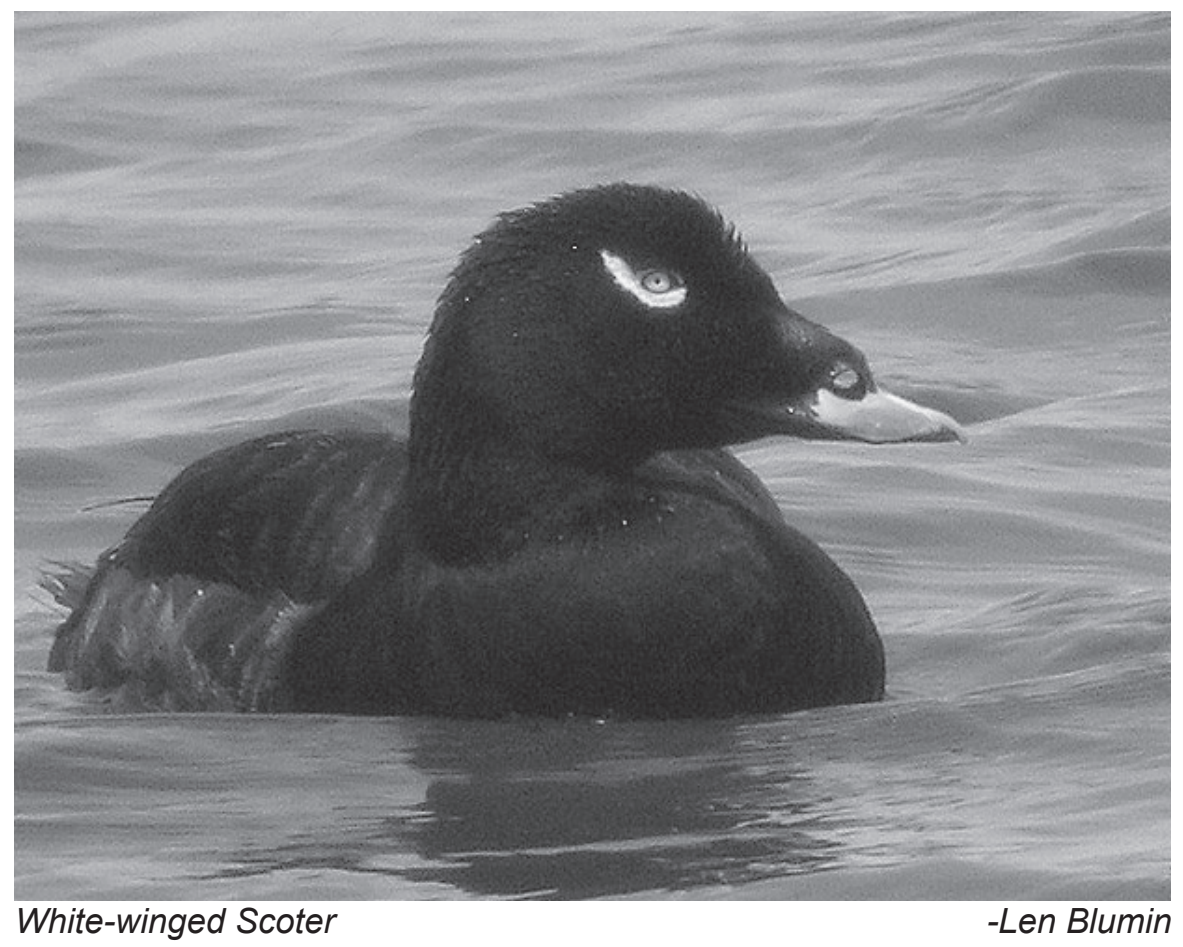

